doi: https://doi.org/10.15407/emodel.41.06.037

UDC 004.942:338.242.2

K.B. Ostapchenko, PhD, Tech., O.I. Lisovychenko, PhD, Tech.

National Technical University of Ukraine

«Igor Sikorsky Kyiv Polytechnic Institute»

(37, Prosp. Peremohy, Kyiv, Ukraine, 03056

e-mail: okb2003@ukr.net; jedak007@gmail.com),

Z.Kh. Borukaiev, Dr. Sci. Tech.

Pukhov Institute for Modeling in Energy Engineering

National Academy of Sciences of Ukraine

(15, Str. General Naumov, Kyiv, Ukraine, 03164

e-mail: zelim_h@ipnet.ua)

\title{
Regulatory Mechanism Model to Stimulate Companies in the Single Buyer Wholesale Market
}

A mathematical model of a regulatory mechanism has been developed for analyzing the profits dynamics of production companies in the context of changes in prices for the main production resources on the wholesale market with a single buyer. This model is based on the further development of the use of the Volterra "predator-prey" mathematical model and the Verhulst logistic equation. An analytical solution has been found for a particular case of the model, which makes it possible to establish the dependencies necessary for making decisions by the market regulator on pricing products and production resources. In order to research the model, computational experiments were carried out, which confirm the reliability of the obtained simulation results and the adequacy of the actual interaction processes in the economic system "producers-single buyer".

K e y w ords: mathematical model, regulatory mechanism, profit, wholesale market

Introduction. One of the most important tasks of organizational management of large production companies and holding companies is the task of planning and analyzing the profits dynamics of controlled enterprises in order to manage the process of obtaining consolidated profits. The formulation of such a goal is associated with the need to ensure equal opportunities in profit-making by structural, territorial divisions of companies, since they are in organizational interaction while providing resources for the production of products and their delivery to final consumers.

(C) Ostapchenko K.B., Lisovychenko O.I., Borukaiev Z.Kh., 2019 
In addition, the possibility of implementing plans for obtaining consolidated profits depends not only on the control actions of the organizational management systems of these companies. Regulatory actions of market authorities on which their products are represented also have a great influence on the formation of profits.

Therefore, at present, the solution of this task is complicated due to the need for timely and adequate consideration of rather sharp fluctuations in prices for raw materials, financial, labor resources, transportation services, etc. The choice of such a task for research is also due to the fact that there are quite a few production companies on the wholesale markets that have their own sales companies, which are single buyers and sellers of the products of these companies.

Related Works. To solve the formulated problem when building a mathematical model, a system of differential equations is used, consisting of the Verhulst equation and the second equation from equations system of the Volterra predator-prey model. Such an approach to building a model was previously repeatedly used to study the dynamics of biological and ecological systems $[1,2]$. Thus, population models with delay have been considered in [3]. In [4] investigate the linear stability of the coexistence steady state and bifurcations occurring from it for Lotka-Volterra diffusion predator-prey system with logistic growth of the prey.

Various modifications of Volterra model for economy modeling are covered in the work [5]. The work [6] focuses on the use of the Lotka-Volterra model for studying the dynamics of macro-behavior of production systems, such as a company, a state, or a country. A diffusive Lotka-Volterra system was formulated in paper [7] that represents the dynamics of market share at duopoly. In recent years, this approach has been used in the construction of mathematical models for studying the dynamics of competitive processes in economic systems $[8,9]$. The focus of these papers is on very important questions of the stability in mathematical equations systems and the search for equilibrium states of economic systems.

This paper is devoted to the development and study of a mathematical model to solve the practical problem of creating a competitive mechanism to stimulate the companies operating in the wholesale market with a single buyer and seller and which using different types of raw materials with different dynamics of price changes to produce a single product.

Examples of such companies can be, for example, those that use the transport service-automobile, water, rail and aviation companies, each of which has its own dynamics of changes in the transportation cost, as well as generating companies of different types operating in the wholesale electric power market with a single regulator or administrator its individual segments. 


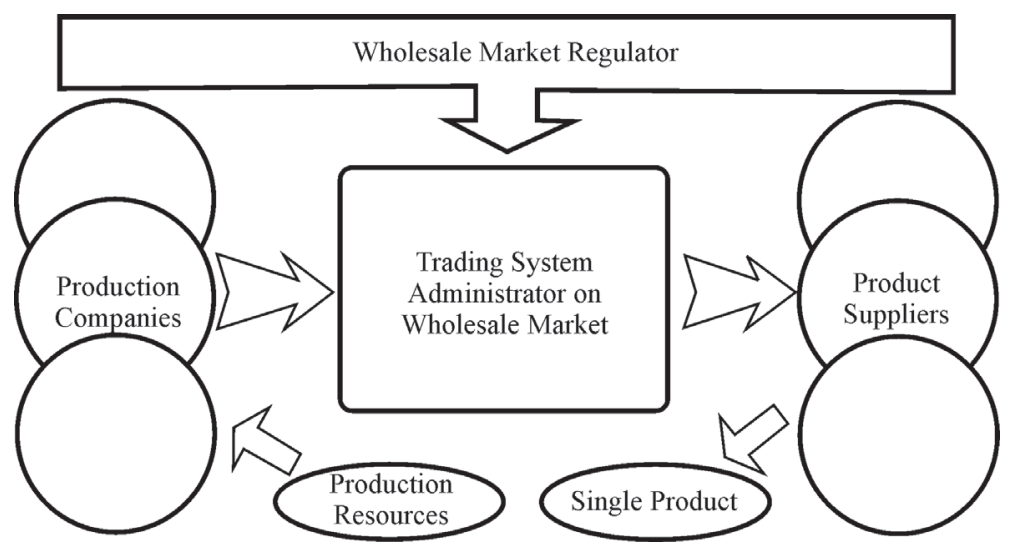

Fig. 1. Organization chart of single Buyer Wholesale Market

Model Building. A distinctive feature of the studied economic system is the presence of one common intermediary (buyer and seller) between production companies and wholesale product suppliers - the Trading System Administrator (TSA). It should be noted that the TSA, although it is not a direct recipient of consolidated profits, however, he is interested in its increase and has the ability to influence the processes of change in profits of producers, through the use of regulatory influences that affect the processes of the common market (Fig. 1).

We will use the same approach proposed in [8] to develop a regulatory mechanism model to stimulate production companies in the "producers-single buyer" economic system. Summarizing it, we obtain an ordinary differential equations system from two types of related components. The first component formalizes the profit growth model for production companies in the form of the Verhulst logistic equation [10], and the second component - for the single product buyer as the second equation from the equations system for Volterra "predator-prey" model [11].

As a result, we come to the model of analyzing the profits dynamics of production companies in the single buyer economic system with a regulated competition between producers in the form of an ordinary differential equations system

$$
\begin{gathered}
\frac{d P_{j}(t)}{d t}=P_{j}(t)\left(a_{j}(t)-b_{j}(t) P_{j}(t)\right), j=\overline{1, n}, \\
\frac{d Y(t)}{d t}=Y(t)\left(-c(t)+\sum_{j=1}^{n} e_{j} P_{j}(t)\right),
\end{gathered}
$$


where $P_{j}(t) \leq P_{j}^{\max }, P_{j}(t)>0$ is a profit of the $j$-th company in the given time interval $t ; P_{j}^{\max }$ is a maximum achievable profit of the $j$-th company; $a_{j}(t)>0$ is a specific rate of profit growth of the $j$-th company; $b_{j}(t)>0$ is a relative cost increase per unit of profit, reflecting competition between producers, caused by limited reserves of production resources and rising prices for them;

$Y(t)$ is a single buyer (TSA) profit; $c(t)=\sum_{j=1}^{n} \alpha_{j} a_{j}(t)>0$ is a specific rate of TSA profit growth; $\alpha_{j}$ is a dimensionless regulatory coefficients established by the TSA, in order to achieve equal conditions in profit making by companies; $e_{j}(t)>0$ is a share of the specific rate of profit growth taken away from the $j$-th company, depending on its share in the total balance of produced products on the market.

If the initial conditions $P_{j}(0)=P_{j}^{0}, Y(0)=Y^{0}$ are specified and the dependences of $a_{j}(t), b_{j}(t), c(t), e_{j}(t)$ are known then the solution of such a system can be found by known numerical methods.

However, the definition of these dependencies seems to be a separate applied task of analyzing the data of the functioning of production companies [12]. Therefore, at this stage of solving the problem under consideration, we confine ourselves to conducting a research of the solution of a particular model obtained from (1) using the simplifying assumptions $a_{j}(t)=a_{j}=\mathrm{const}, b_{j}(t)=b_{j}=\mathrm{const}$, $P_{j}(t) \leq P_{j}^{\max }=$ const,$e_{j}(t)=e_{j}=$ const,$c(t)=\sum_{j=1}^{n} \alpha_{j} a_{j}=$ const.

Let as the initial conditions set the basic values of profit achieved by producers $P_{j}(0)=P_{j}^{0}$ and a product single buyer $Y(0)=Y^{0}$ in the previous interval to the calculated time interval $t$. Then, the equations from system (1), relative to $P_{j}(t)$ and $Y(t)$, allow obtaining a common analytical solution by applying the variable separation method.

As a result, the solution of this equations system for given initial conditions and assumptions will be as follows

$$
P_{j}(t)=\frac{K_{j} P_{j}^{0} e^{a_{j} t}}{K_{j}+P_{j}^{0}\left(e^{a_{j} t}-1\right)}, K_{j}=\frac{a_{j}}{b_{j}}
$$




$$
Y(t)=\frac{Y^{0}}{\prod_{j=1}^{n} K_{j}^{\frac{e_{j}}{b_{j}}}} \cdot e^{-\sum_{j=1}^{n} \alpha_{j} a_{j} t} \cdot \prod_{j=1}^{n}\left(K_{j}+P_{j}^{0}\left(e^{a_{j} t}-1\right)\right)^{\frac{e_{j}}{b_{j}}}
$$

By direct substitution, it is easy to verify that functions (2) and (3) satisfy the equations system (1) and the initial conditions.

Model Studying. The purpose of computational experiments is to research the obtained particular solution of the system (1) to confirm the reliability of the simulation results and the adequacy of the model to the real process of economic interaction between producers and a product single buyer.

The validation of the simulation results will be carried out by solving an applied problem of modeling the profit dynamics of production companies operating in the wholesale electric power market with a single buyer and seller in the context of changing energy prices.

In this paper, the term "profit" is used in the conventional sense, as the difference between the sales proceeds of produced electric power $B_{p}(t)$ (excluding value-added tax) and the general conditionally variable and conditionally fixed costs for its production and sale $Z(t)$, included in the production cost for the time interval $t[13]$ :

$$
P_{p}(t)=B_{p}(t)-Z(t), t \in[1, T] .
$$

For the considered example of the applied problem, we introduce the next notation $P_{j}(t)$ as a profit of generating companies - electric power producers operating in the wholesale market, such as nuclear power plants (NPP), thermal power plants (TPP), hydroelectric power plants (HPP), thermal energy plants (TEP), wind power plants (WPP), solar power plants (SPP), where $j \in\{$ TPP, TEP, NPP, HPP, WPP, SPP $\}$. Then their total consolidated profit is $P_{p}(t)=\sum_{j} P_{j}(t)$.

Analysis of the selling prices of generating companies of NPP, WPP, SPP, which are established by the Wholesale Market Regulator, shows that for quite long periods of time they remain unchanged $[12,14]$, and the volumes of produced electric power undergo minor changes as they are limited by technological capabilities. Fluctuations in the volumes of produced electric power from HPP and prices for it are more substantial and seasonal. But also, as well as the NPP, WPP, SPP, the HPP companies produce electric power at contrac- 
tual prices. It can be assumed that the share of their profits remains unchanged in the total profit balance and is not directly dependent on changes in energy prices. Those, total profit can be represented as

$$
P_{p}(t)=P_{T P P}(t)+P_{T E P}(t)+P_{A},
$$

where $P_{A}=P_{N P P}+P_{H P P}+P_{W P P}+P_{S P P}$ is a fixed profit component over a relatively long time period $T$.

It is obvious that the expected (planned) profit of market participants depends on the planned volume of produced electric power by generating companies $E_{j}(t)$ and the forecast wholesale price of its purchase on the wholesale market $C_{\text {market }}^{\text {foreast }}(t)$ :

$$
P_{j}(t)=\left(C_{\text {market }}^{\text {forecast }}(t)-C_{j}(t)\right) E_{j}(t),
$$

where $C_{j}(t)$ is a actual selling price per unit of electric power produced by generating companies.

Therefore, we will further consider the questions of model research, relating only to the profit dynamics of TPP and TEP generating companies operating under the conditions of the "Single Buyer and Seller" market model and consuming various energy resources - coal (first resource) and gas (second resource) for electric power production.

In our case, the economic system will consist of two types of generating companies - TPP $(j=1)$, TEP $(j=2)$ and a single buyer - TSA. It should be noted that the TSA, although it is not a direct recipient of profit, but he is interested in increasing it. He has the opportunity, as noted above, together with the Market Regulator to influence the processes of changing producers' profits through the use of regulatory actions that affect the market processes.

As a result, we have a system consisting of three equations

$$
\begin{gathered}
\frac{d P_{j}(t)}{d t}=P_{j}(t)\left(a_{j}(t)-b_{j}(t) P_{j}(t)\right), j=\overline{1,2}, \\
\frac{d Y(t)}{d t}=Y(t)\left(-c(t)+\sum_{j=1}^{2} e_{j}(t) P_{j}(t)\right) .
\end{gathered}
$$

As the initial data we set the following values of the initial conditions of 

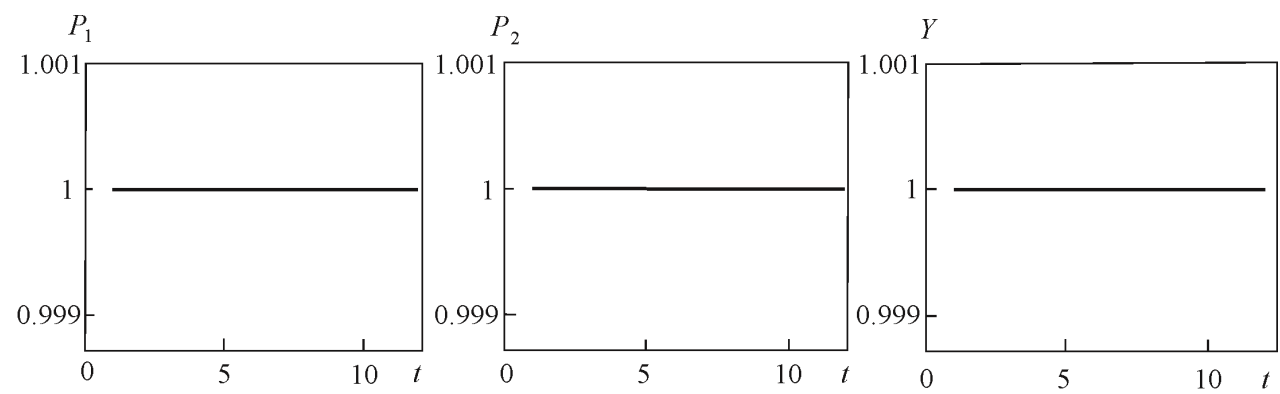

Fig. 2. Experiment No.1 for equilibrium variant of profit distribution

the desired variables and parameters for the 12-months time period of the calendar year:

$$
\begin{gathered}
t_{0}=0, t=\overline{1,12}, P_{1}\left(t_{0}\right)=1, P_{2}\left(t_{0}\right)=1, Y\left(t_{0}\right)=1, \\
a_{1}=a_{2}=0.5, b_{1}=b_{2}=0.5, \alpha_{1}=\alpha_{2}=1, e_{1}=e_{2}=0.5 .
\end{gathered}
$$

The exact solution of the system (4) according to the given initial data may be easy to find from the expressions (2), (3). This solution is $P_{1}(t)=1$, $P_{2}(t)=1, Y(t)=1, t=\overline{1,12}$.

The same result was obtained when conducting a test numerical solution of the equations system (4), using expressions (2), (3). To verify the reliability of the results of numerical simulation, the solution of the same task was carried out using the Runge-Kutta numerical method. A similar result was obtained with almost zero error. In addition, the result of the test confirms the possibility of applying the proposed model for analyzing the profit dynamics of generating companies and a single buyer for the actual number of electric power producers market participants using different types of energy resources.

Computational Experiments. A series of computational experiments were carried out to confirm the adequacy of the profit dynamics model of generating companies to the real process of economic interaction between producers and a single buyer and the possibility of its application for preparing and making justified decisions to regulate the profit making process by all subjects of the considered economic system.

As a result of the first experiment, an equilibrium variant of profit distribution between a single buyer and companies using two different types of energy resources for electric power production was determined and adopted as the basic one. We assume that this distribution is agreed by all subjects of the economic system. On Fig. 2 shows the experimental results obtained for the following values of the initial conditions for a 12-month time period: $t_{0}=0$, 

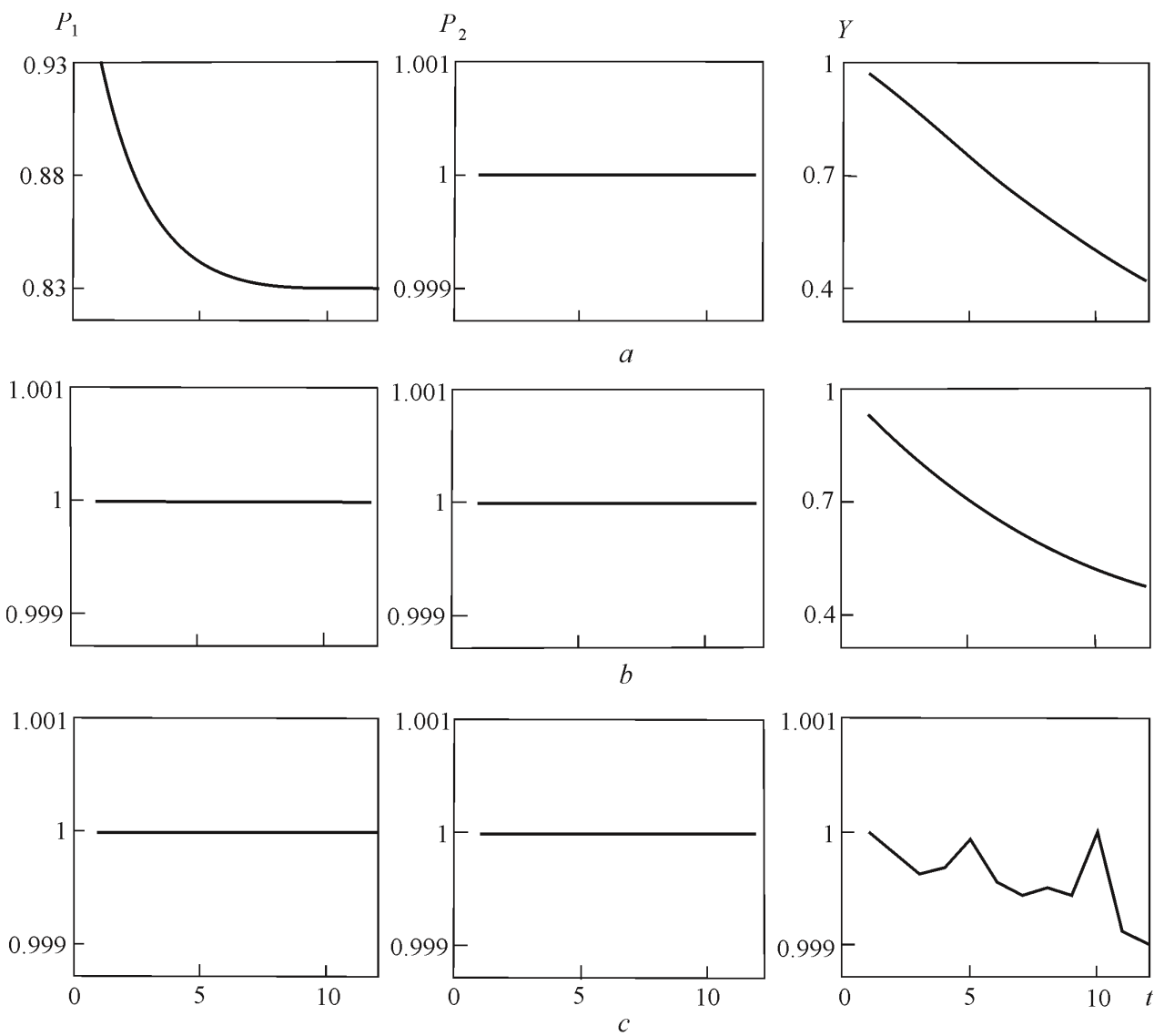

Fig. 3. The results of experiments $2-4: a$ - experiment $2-b_{1}=0.6 ; b-$ experiment $3-a_{1}=0.6$, $b_{1}=0.6 ; c$ - experiment $4-a_{1}=0.6, b_{1}=0.6, e_{1}=0.6$

$t=\overline{1,12}, P_{1}\left(t_{0}\right)=1, P_{2}\left(t_{0}\right)=1, Y\left(t_{0}\right)=1, a_{1}=a_{2}=0.5, b_{1}=b_{2}=0.5, \alpha_{1}=\alpha_{2}=1$, $e_{1}=e_{2}=0.5$.

Further experiments were carried out for three possible cases of increasing in prices of energy resources (Fig. 3).

In the first case, the initial conditions and values of the parameters remain unchanged, except for the parameter $b_{1}$, which increased by $20 \%$ as a result of the increase in prices for the first energy resource: $t_{0}=0, t=\overline{1,12}$, $P_{1}\left(t_{0}\right)=1, P_{2}\left(t_{0}\right)=1, Y\left(t_{0}\right)=1, a_{1}=0.5, a_{2}=0.5, b_{1}=0.6, b_{2}=0.5, \alpha_{1}=1$, $\alpha_{2}=1, e_{1}=0.5, e_{2}=0.5$.

The calculation results show (Fig. 3,a) that the profits of the first company and the single buyer decrease. But the regulator has the opportunity, using 
the parameter $a_{1}$, to change the size of profit received by the first company and set it at the same level.

For this, the following experiment was conducted, as a result of which the size of the increase in the purchase price of electric power was determined to restore the basic level of profit for the first company by choosing the appropriate parameter $a_{1}$ (Fig. 3, $b$ ): $t_{0}=0, t=\overline{1,12}, P_{1}\left(t_{0}\right)=1, P_{2}\left(t_{0}\right)=1, Y\left(t_{0}\right)=1$, $a_{1}=0.6, a_{2}=0.5, b_{1}=0.6, b_{2}=0.5, \alpha_{1}=1, \alpha_{2}=1, e_{1}=0.5, e_{2}=0.5$.

Next experiments were conducted for the case when the initial conditions and values of the parameters remain unchanged, except for the parameter $b_{2}$, which also increased by $20 \%$ as a result of the increase in prices for the second energy resource. The results obtained are similar to those shown in Fig. 3, $a$ and 3, $b$.

Another case was also considered when the values of parameters $b_{1}$ and $b_{2}$ increased by $20 \%$ as a result of the increase in prices for both energy resources with the rest input data unchanged. A natural result was obtained in which the profits of both production companies and the single buyer in all cases are reduced. Thus, it becomes necessary to make regulatory decisions to increase the wholesale price for the purchase of electric power from both production companies.

A final series of experiments was carried out to determine the profit share taken away from production companies by a single buyer in order to restore the basic level of its profit, which was before the increase in energy resource prices. This problem is solved by selecting the values of the parameters $e_{1}$ and $e_{2}$. In Fig. 3, $c$ shows the results of one experiment obtained for the case when the price of the first energy resource (parameter $b_{1}$ ) and the size of the first company's profit (parameter $a_{1}$ ) increased: $t_{0}=0, t=\overline{1,12}, P_{1}\left(t_{0}\right)=1$, $P_{2}\left(t_{0}\right)=1, \quad Y\left(t_{0}\right)=1, a_{1}=0.6, a_{2}=0.5, \quad b_{1}=0.6, \quad b_{2}=0.5, \quad \alpha_{1}=1, \quad \alpha_{2}=1$, $e_{1}=0.6, e_{2}=0.5$.

In this case, a value for the parameter $e_{1}=0.6$, has been determined to restore the basic level of single buyer profit.

The results of computational experiments are illustrative and obtained using by Mathcad 15. It is obvious that for practical use of the proposed mathematical model, it is necessary to build a computer model with developed modeling algorithms and visualization tools. In particular, in order to select the optimal values of the regulatory (adjustable) model parameters, when searching for the required level of profit to be obtained by all subjects of the economic system, it is necessary to use the appropriate calculation algorithms. 
The development of such algorithms, including for a larger number of companies and types of energy resources, is not a difficult task. It can be solved using well-known numerical optimization methods and will be investigated in subsequent papers.

\section{Conclusions}

A model of the regulatory stimulating mechanism in the economic system of interaction of production companies with a single buyer has been developed. It allows analyzing and regulating the impact of changes in the prices of production resources on the profits of the wholesale market participants. Analytical solutions are found for a particular case of the model, that allow to establish the dependencies necessary for making regulatory decisions on the pricing of products and production resources.

A simulation model was developed for the profit dynamics of generating companies operating in the wholesale electric power market with a single buyer and seller in the context of changes in prices of energy resources. Computational experiments on the model confirmed the reliability of the simulation results and showed the possibility of using them to solve the organizational management problems of the wholesale market related to making decisions on the pricing of electric power and energy resources.

\section{REFERENCES}

1. Goel, N.S., Maitra, S.C. and Montroll, E.W. (1971), "On the Volerra and other nonlinear models of interacting population", Reviews of Modern Physics, Vol. 43, no. 2, pp. 231-276.

2. Wang, J., Shi, J. and Wei, J. (2011), "Dynamics and pattern formation in a diffusive predatorprey system with strong Allee effect in prey”, Journal of Differential Equations, Vol. 251, no. 4-5, pp. 1276-1304.

3. Gopalsamy, K. (1992), Stability of Oscillations in Delay Differential Equations of Population Dynamics, Springer, Dordrecht, Netherlands.

4. Gourley, S.A. and Britton, N.F. (1996), "A predator-prey reaction-diffusion system with nonlocal effects", Jornal of Mathematical Biology, Vol. 34, no. 3, pp. 297-333.

5. Prasolov, A.V. (2001), "Mathematical models of the interaction of firms as a tool of corporate management", News of St.Petersburg University of Economics and Finance, No. 2, pp. 32-47.

6. Kamimura, A., Burani, G.F. and Franca, H.M. (2011), "The economic system seen as a living system: A Lotka-Volterra framework", Emergence: Complexity\&Organization, Vol. 13, no. 3, pp. 80-93.

7. Wijeratne, A.W., Yi, F. and Wei, J. (2009), "Bifurcation analysis in the diffusive LotkaVolterra system: an application to market economy", Chaos, Solitons\&Fractals, Vol. 40, no. 2, pp. 902-911.

8. Alrefai, W.A. and Naumeyko, I.V. (2014), "The development of mathematical model for competitive processes", Eastern-European Journal of Enterprise Technologies, Vol. 5, no. 3 (71), pp. 55-60. 
9. Aliluyko, A.N. (2013), "Research of dynamics of interaction of enterprises applying Lotka-Volterra competition model", Eastern-European Journal of Enterprise Technologies, Vol. 1, no. 3(61), pp. 25-29.

10. Plusnina, T.Y., Fursova, P.V., Terlova, L.D. and Riznichenko, G.Y. (2014), Mathematical models in biology, RCD, Moscow, Russia.

11. Volterra, V. (1976), Mathematical theory of the struggle for existence, Nauka, Moscow, Russia.

12. Borukaev, Z.Kh., Ostapchenko, K.B. and Lisovychenko, O.I. (2015), “Analysis of the interrelation of data on the energy market dynamics with price changes in the energy resources ' markets", Adaptive systems of automatic control, Vol. 1, no. 26, pp. 46-64.

13. Kozhevnikov, N.N. (2004), Economics and management of energy enterprises, Publishing Center "Academy", Moscow, Russia.

14. Borukaev, Z.Kh., Ostapchenko, K.B. and Lisovychenko, O.I. (2014), "Modeling the dynamics of the energy market in the context of price changes in the energy resources markets", Modeling and Information Technologies, No. 73, pp. 139-146.

Received 25.10.19

\section{К.Б. Остапченко, О.И. Лисовиченко, З.Х. Борукаев}

\section{МОДЕЛЬ РЕГУЛЯТОРНОГО МЕХАНИЗМА СТИМУЛИРОВАНИЯ КОМПАНИЙ НА ОПТОВОМ РЫНКЕ С ЕДИНЫМ ПОКУПАТЕЛЕМ}

Разработана математическая модель регуляторного механизма анализа динамики прибыли производственных компаний в условиях изменения цен на основные ресурсы производства на оптовом рынке с единым покупателем. Эта модель создана на основе дальнейшего развития применения математической модели Вольтерра «хищникжертва» и логистического уравнения Ферхюльста. Найдено аналитическое решение для частного случая модели, позволяющее установить зависимости необходимые при принятии решений регулятором рынка по формированию цен на продукцию и ресурсы производства. С целью исследования модели проведены вычислительные эксперименты, которые подтверждают достоверность получаемых результатов моделирования и адекватность реальным процессам взаимодействия в экономической системе «производители-единый покупатель продукции».

Ключев в е слова: математическая модель, регуляторный механизм, прибыль, оптовый рынок.

К.Б. Остапченко, О.І. Лісовиченко, З.Х. Борукаєв

\section{МОДЕЛЬ РЕГУЛЯТОРНОГО МЕХАНІЗМУ \\ СТИМУЛЮВАННЯ КОМПАНІЙ НА ОПТОВОМУ РИНКУ З ЄДИНИМ ПОКУПЦЕМ}

Розроблено математичну модель регуляторного механізму аналізу динаміки прибутку виробничих компаній в умовах зміни цін на основні ресурси виробництва на оптовому ринку з єдиним покупцем. Ця модель створена на основі подальшого розвитку застосування математичної моделі Вольтерра «хижак-жертва» і логістичного рівняння Ферхюльста. Знайдено аналітичний розв'язок для окремого випадку моделі, що дозволяє 
встановити залежності необхідні при прийнятті рішень регулятором ринку по формуванню цін на продукцію і ресурси виробництва. 3 метою дослідження моделі проведені обчислювальні експерименти, які підтверджують достовірність отриманих результатів моделювання і адекватність реальним процесам взаємодії в економічній системі «виробники-єдиний покупець продукції».

Ключ ю в і сл о в а: математична модель, регуляторний механізм, прибуток, оптовий ринок.

OSTAPCHENKO Konstantin Borisovych, Cand. of sciences (engineering), associate professor, associate professor of Technical Cybernetics Department National Technical University of Ukraine «Igor Sikorsky Kyiv Polytechnic Institute», graduated from Kiev Polytechnic Institute in 1986. The field of scientific research - modeling and software of computerized integrated systems.

LISOVYCHENKO Oleh Ivanovych, Cand. of sciences (engineering), associate professor, associate professor of Technical Cybernetics Department National Technical University of Ukraine "Igor Sikorsky Kyiv Polytechnic Institute», graduated from National Technical University of Ukraine «Igor Sikorsky Kyiv Polytechnic Institute» in 1999. The field of scientific research modeling complex systems and intelligent decision making systems.

BORUKAIEV Zelim Kharitonovych, Doctor of sciences (engineering), senior scientific worker, leading scientific worker of the Department of Mathematical and Econometric Pukhov Institute for Modelling in Energy Engineering National Academy of Sciences of Ukraine, graduated from Rostov State University in 1971. The field of scientific research - mathematical modeling of physical fields and processes, modeling of information processes and systems. 